\section{OPTIMALISASI DANA CSR UNTUK PARIWISATA HALAL JAWA TENGAH: STUDI KASUS WISATA BLEDUG KUWU, GROBOGAN}

\author{
Pratika Hanafiah, Afta Serti Mardita, Lisdiana Safitri \\ Akutansi, Fakultas Ekonomi, Universitas Negeri Semarang \\ pratikajsj@gmail.com
}

DOI: https://doi.org/10.21107/dinar.v6i2.6463

\begin{abstract}
Abstrak
Global Muslim Travel Index (GMTI) 2018 mencatat bahwa Indonesia menempati urutan kedua sebagai wisata halal paling populer di dunia. Indonesia juga negara dengan populasi Muslim terbesar di dunia, total 228 juta Muslim yang beragam pada tabun 2017, menjadikan Indonesia memiliki potensi besar pengembangan pariwisata balal. Salab satunya adalah Bledug Kuwu, pariwisata fenomena alam yang memuntabkan lumpur dari bumi dan memberikan manfaat besar bagi masyarakat. Namun, pengelolaan pariwisata tersebut belum maksimal, diantaranya adalah adanya beberapa infrastruktur dan fasilitas yang tidak memadai.

Penelitian ini bertujuan menemukan solusi kurangnya fasilitas dan infrastruk.tur dengan Corporate Social Responsibility (CSR). Metode penelitian ini menggunakan metode kualitatif dengan pendekatan eksploratif deskriptif.

Hasil penelitian mengungkapkan babwa CSR dapat berkontribusi pada tujuan pembangunan berkelanjutan yang dapat digunakan sebagai sarana pengembangan pariwisata halal di Indonesia. Melalui dana CSR yang saling berkolaborasi antara Bledug Kunu dan lembaga penyalur, yaitu Lembaga Penyalur CSR Indonesia (LPCI), dapat berkontribusi besar mewujudkan Bledug Kuwn sebagai pariwisata halal dengan membangun beberapa infrastruktur, fasilitas dan layanan berdasarkan Syariah dan menyediakan inovasi baru, seperti mendidik wisatawan dan dana CSR ini dapat menjadikan Bledug kuwu sebagai wisata halal paling populer di Grobogan dan babkan Jawa Tengah.
\end{abstract}

\section{Kata Kunci: Kuwu Bledug, Pariwisata Halal, CSR}




\section{PENDAHULUAN}

Salah satu output perusahaan yang tengah menjadi pembicaraan hangat adalah Corporate Social Responsibility atau tanggung jawab sosial perusahaan. Beragam model CSR terus muncul ditengah kehidupan masyarakat, bisa dalam bentuk penanaman kembali hutan, pembuatan sarana/prasarana masyarakat hingga dikembalikan kembali pada masyarakat dalam bentuk uang. Lembaga Penyalur CSR Indonesia (LPCI) menjadi salah satu tujuan perusahaan dalam menyalurkan dana CSR mereka.

Dana CSR yang terbilang cukup besar di Indonesia dapat dikelola untuk berbagai hal, seperti pendidikan, industri, kesehatan bahkan pariwisata. Mastercard Crescent Rating kembali meluncurkan hasil Studi Global Muslim Travel Index (Crescentrating, 2018), mengungkapkan Indonesia berhasil naik satu peringkat menjadi rangking 2 sebagai destinasi pariwisata halal terpopuler di dunia. Indonesia berhasil menduduki posisi dua bersama Uni Emirat Arab dengan total nilai 72,8. Indonesia dianugrahi sebagai penduduk dengan populasi umat muslim terbesar di dunia dengan total 222 juta jiwa lebih penganut agama Islam. Dari data tersebut Indonesia memiliki potensi besar akan wisata halalnya untuk di kembangkan lagi melalui pemanfaatan dana CSR. Salah satunya di pedesaan pedesaan memiliki potensi besar untuk dikembangkan menjadi pariwisata halal seperti daerah Kabupaten Grobogan Jawa tengah.

Grobogan adalah salah satu Kabupaten di Provinsi Jawa Tengah, dengan tanah seluas 1,97 juta km persegi yang menjadikan Grobogan sebagai kabupaten terluas kedua di Jawa Tengah. Secara geogafis, Grobogan merupakan lembah yang diapit oleh dua pegunungan kapur, yaitu Pegunungan Kedeng dan Pegunungan Kapur Utara. Ternyata dengan kondisi kering dan gersang yang menyelimuti tanah ini, Grobogan memiliki potensi alam akan pariwisata, yaitu berupa Bledug Kuwu.

Bledug Kuwu (Sabdaningsih, 2018) merupakan sebuah kawasan semburan lumpur yang terletak di Desa Kuwu, Kota Purwodadi, Kabupaten Grobogan. Lokasi ini persis di pinggir jalan utama yang menghubungkan antara Kota Purwodadi dan Blora, sehingga dapat mempermudah masyarakat untuk melihat semburuan lumpur Bledug Kuwu tersebut. Selain mengeluarkan semburan lumpur, Bledug Kuwu ini menghasilkan suara yang cukup keras berupa bunyi bledug bledug dari gelembung lumpur bersamaan dengan keluarnya asap, gas, dan air garam. Bledug Kuwu ini dapat menghasilkan beberapa potensi yanag sangat besar, seperti air garam yang diolah menjadi dapur garam dan semburan lumpur untuk dijadikan kosmetik atau bahan kecantikan lainnya. Dengan adanya sumber manfaat besar yang terkandung dalam Bledug Kuwu tersebut, tetapi kurangnya pengetahuan masyarakat akan manfaat Bledug Kuwu menjadikan masyarakat enggan untuk mengelola dan memanfaatkan hal tersebut bagi masyarakat sendiri. 
Melalui pengelolaan dana CSR yang baik dapat menjadikan Bledug Kuwu sebagai pariwisata halal yang mengandung nilai edukasi di dalamnya. LPCI merupakan lembaga yang cocok bagi perusahaan untuk menyalurkan dananya (Bariyah, 2016). Pada saat ini, LPCI tidak fokus untuk menyalurkan dananya dibidang pariwisata, oleh karena itu, kita perlu mengembangkan lagi terkait dana yang dikelola LPCI untuk industri pariwisata. Penyaluran dana melalui Lembaga Penyalur CSR Indonesia (LPCI) dapat membantu mengembangkan Bledug Kuwu sebagai pariwisata halal berupa wisata edukasi.

\section{TINJAUAN PUSTAKA}

\section{Bledug Kuwu}

Bledug Kuwu merupakan tempat wisata alam yang terletak di Desa Kuwu, Kecamatan Kradenan, berjarak sekitar 30 kilometer kearah timur Kota Purwodadi, Kabupaten Grobogan. Lokasi dengan lahan kosong seluas 45 hektar yang menyajikan fenomena alam berupa semburan lumpur yang mengeluarkan suara bledug bledug dari perut bumi. Objek wisata Bledug Kuwu dikelola pemerintah Kabupaten Grobogan sejak 1983. Jumlah pengunjung terus mengalami peningkatan signifikan setiap tahunnya. Pada tahun 2016 jumlah pengunjung mencapai 26 ribu orang. Lalu pada tahun 2017 rata rata perhari 70 orang datang berkunjung untuk melihat semburan lumpur tersebut. Untuk hari hari libur besar seperti libur lebaran dapat mencapai 500 orang perharinya.

Sayangnya destinasi yang mempesona ini tak dibarengi dengan fasilitas fasilitas menunjang yang memadai. Beberapa gazebo ala kadarnya yang tersedia sudah tak lagi layak. Gazebo telah rusak dan usang dimakan usia, tidak ada penghijauan atau pepohonan sama sekali, jembatan bambu sebagai sarana menuju lokasi letupan juga sudah hancur sana sini. Terlebih, banyak sampah berserakan yang ditemukan. Mushola hingga MCK juga kurang dipercantik. Menurut hasil penelitian secara geologi apa yang terjadi pada bledug kuwu adalah suatu proses alam yang disebut fenomena Gunung Api Lumpur (mud volcanoes), sebuah fenomena ekstrusi cairan seperti hidrokarbon dan gas methane.

Bledug Kuwu ini dapat menghasilkan beberapa potensi yang sangat besar, seperti air garam yang diolah menjadi garam dapur dan semburan lumpur untuk dijadikan kosmetik atau bahan kecantikan lainnya. Tetapi kurangnya pengetahuan masyarakat akan manfaat Bledug Kuwu menjadikan masyarakat enggan untuk mengelola dan memanfaatkan hal tersebut bagi masyarakat sendiri, serta Bledug Kuwu belum mendapat perhatian secara khusus dari pemerintah maupun dinas pariwisata setempat untuk dijaikan pariwisata halal berupa wisata edukasi.

\section{Pariwisata Halal}

Pariwisata Islami atau halal merupakan kegiatan yang didukung berbagai fasilitas serta layanan yang disediakan masyarakat, pengusaha, pemerintah, dan pemerintah daerah yang 
memenuhi syariah Islam (Adinugraha \& Sartika, 2019). Fasilitas dan layanan yang disediakan tersebut tidak berbeda dengan fasilitas umum lainnya, hanya saja fasilitas dan layanan yang disediakan tidak bertentangan dengan nilai nilai islam. Sehingga masyarakat muslim dapat menikmati fasilitas dan layanan yang disediakan dengan leluasa.

Selain istilah wisata syariah, dikenal juga halal tourism atau wisata halal. Wisata halal merupakan konsep baru pariwisata. Ini bukanlah wisata religi seperti umroh atau pergi haji. Wisata halal adalah pariwisata yang melayani liburan, dengan menyesuaikan gaya liburan sesuai dengan kebutuhan dan permintaan traveler muslim. Dengan hal ini hotel mengusung prinsip syariah tidak melayani minuman beralkohol dan memiliki kolam renang dan fasilitas spa terpisah untuk pria dan wanita (Wuryasti, 2013).

Berdasar pengertian diatas, konsep syariah yang tidak melanggar atau tidak bertentangan dengan nilai nilai dan etika syariah berhubungan dengan konsep halal dan haram didalam Islam (Nugroho, Utami, \& Doktoralina, 2019). Halal diartikan dibenarkan, sedangkan haram diartikan dilarang. Konsep halal dapat dilihat dari dua perspektif agama dan prespektif industri. Yang dimaksud dengan perspektif agama yaitu sebagai hukum makanan apa saja yang boleh dikonsumsi oleh konsumen muslim. Sedangkan dalam perspektif industri, bagi produsen pangan, konsep halal ini dapat diartikan sebagai suatu peluang bisnis (Rama, 2014).

Menurut (Hakim, Ridwan, Hasanuddin, \& Al-Hakim, 2017) ada delapan faktor standar dalam pengukuran pariwisata syariah dari segi administrasi dan pengelolaannya untuk semua wisatawan, hal tersebut dapat menjadi suatu karakteristik tersendiri, yaitu:

Pelayanan kepada wisatawan haruslah cocok dengan prinsip muslim secara keseluruhan

1. Pemandu dan staf harus memiliki disiplin dan menghormati prinsip-prinsip Islam.

2. Mengatur semua kegiatan agar tidak bertentangan dengan prinsip Islam.

3. Bangunan harus sesuai dengan prinsip-prinsip Islam.

4. Restoran harus mengikuti standar internasional pelayanan halal.

5. Layanan transportasi harus memiliki keamanan sistem proteksi.

6. Ada tempat-tempat yang disediakan untuk semua wisatawan muslim melakukan kegiatan keagamaan.

7. Bepergian ke tempat-tempat yang tidak bertentangan dengan prinsip.

Dari karakteristik pariwisata syariah yang dijabarkan di atas, terdapat empat aspek penting yang harus diperhatikan untuk menunjang suatu pariwisata syariah (Soebagyo, 2018), Pertama terkait lokasi penerapan sistem Islami di area pariwisata. Lokasi pariwisata yang dipilih merupakan yang diperbolehkan kaidah Islam dan dapat meningkatkan nilai-nilai Spiritual wisatawan. Kedua, adalah transportasi, penerapan sistem, seperti pemisahan tempat duduk antara laki-laki dan wanita yang bukan mahram sehingga tetap berjalannya syariat Islam dan terjaganya kenyamanan wisatawan (Adinugraha, Sartika, \& Kadarningsih, 
2018). Ketiga adalah ketersediaan konsumsi yang halal. Islam sangat memperhatikan segi kehalalan konsumsi, hal tersebut tertuang dalam Q.S Al-Maidah ayat 3. Segi kehalalan disini baik dari sifatnya, perolehannya maupun pengolahannya (Zulaekah, Yuli Kusumawati, 2005). Selain itu, suatu penelitian menunjukkan bahwa minat wisatawan dalam makanan memainkan peran sentral dalam memilih tujuan wisata (Crescentrating, 2017). Keempat adalah Penginapan, yaitu hotel: Seluruh proses kerja dan fasilitas yang disediakan berjalan sesuai dengan prinsip syariah. Menurut (Soebagyo, 2018), pelayanan disini tidak sebatas dalam lingkup makanan maupun minuman, tetapi juga dalam fasilitas yang diberikan seperti spa, gym, kolam renang, ruang tamu dan fungsional untuk laki-laki dan perempuan sebaiknya dipisah.

Di Indonesia sendiri mulai banyak objek objek wisata yang menerapkan sistem pariwisata halal dan objek wisata tersebut tergolong sukses untuk meningkatkan harga jual mereka. Seperti contoh Wisata Danau Singkarak di Kepulauan Mentawai, Wisata Pantai Syariah Pulau Santen di Karangrejo Banyuwangi, Beberapa spot di Pulau Bali, Hotel Hotel Syariah di Kota Pekalongan, dan masih banyak lagi (Jaelani, 2017).

Dari sekian banyak wisata halal yang telah tersedia di Indonesia, wisata alamlah yang mendominasi. Hal ini menjadikan Bledug Kuwu sebagai objek yang menarik dan potensial untuk dikembangkan menjadi wisata halal selanjutnya. Ditambah 98,9 persen atau sekirar 1.766.260 jiwa penduduk Grobogan adalah penganut Agama Islam (Data BPS 2015) membuat Wisata Halal Bledug Kuwu yang akan dikembangkan lebih menjanjikan.

\section{CSR (Corporate Social Responsibility)}

CSR (Corporate Social Responsibility) adalah suatu konsep atau tindakan yang dilakukan oleh perusahaan sebagai rasa tanggung jawab perusahaan terhadap sosial maupun lingkungan sekitar dimana perusahaan itu berada, seperti melakukan suatu kegiatan yang dapat meningkatkan kesejahteraan masyarakat sekitar dan menjaga lingkungan, memberikan beasiswa untuk anak tidak mampu di daerah tersebut, dana untuk pemeliharaan fasilitas umum, sumbangan untuk membangun desa/fasilitas masyarakat yang bersifat sosial dan berguna untuk masyarakat banyak, khususnya masyarakat yang berada di sekitar perusahaan tersebut berada.

Corporate Social Responsibility (CSR) merupakan sebuah fenomena dan strategi yang digunakan perusahaan untuk mengakomodasi kebutuhan dan kepentingan stakeholder-nya (Tanudjaja, 2006). CSR dimulai sejak era dimana kesadaran akan sustainability perusahaan jangka panjang adalah lebih penting daripada sekedar profitability perusahaan (Retno \& Priantinah, 2012).

Kegiatan CSR akan menjamin keberlanjutan bisnis yang dilakukan. Hal ini disebabkan karena menurunnya gangguan sosial yang sering terjadi akibat pencemaran lingkungan, bahkan dapat menumbuh kembangkan dukungan atau pembelaan masyarakat setempat dan 
agar pasokan bahan baku secara berkelanjutan terjamin untuk jangka panjang. Tambahan keuntungan dari unit bisnis baru, yang semula merupakan kegiatan CSR yang dirancang oleh korporat.

Adapun 5 pilar yang mencakup kegiatan CSR yaitu: Pengembangan kapasitas SDM di lingkungan internal perusahaan maupun lingkungan masyarakat sekitarnya; Penguatan ekonomi masyarakat sekitar kawasan wilayah kerja perusahaan; Pemeliharaan hubungan relasional antara korporasi dan lingkungan sosialnya yang tidak dikelola dengan baik sering mengundang kerentanan konflik; Perbaikan tata kelola perusahaan yang baik dan pelestarian lingkungan, baik lingkungan fisik, sosial serta budaya.

Berikut ini adalah manfaat CSR bagi masyarakat yaitu meningkatknya kesejahteraan masyarakat sekitar dan kelestarian lingkungan; adanya beasiswa untuk anak tidak mampu di daerah tersebut; meningkatnya pemeliharaan fasilitas umum fsm adanya pembangunan desa/fasilitas masyarakat yang bersifat sosial dan berguna untuk masyarakat banyak khususnya masyarakat yang berada di sekitar perusahaan tersebut berada.

Sedang bagi perusahaan, manfaat CSR yaitu dapat meningkatkan citra perusahaan, mengembangkan kerja sama dengan perusahaan lain, memperkuat brand merk perusahaan di mata masyarakat, membedakan perusahan tersebut dengan para pesaingnya dan memberikan inovasi bagi perusahaan

\section{Lembaga Penyalur CSR Indonesia (LPCI)}

Maksud dan tujuan menumbuh kembangkan kesadaran Perusahaan-perusahan Swasta Nasional maupun Multinasional untuk melaksanakan aturan CSR (Corporate Social Responsibility), diseluruh wilayah Republik Indonesia sesuai dengan Regulasi Pemerintah yang ada serta mengelola dan atau mengkoordinir serta menyalurkan Dana CSR ini secara Transparan dan Akuntabel. LPCI juga berfungsi sebagai sebagai generator, motivator, kordinator, investigator, dan fasilitator (CSR Match Maker) serta pengelola dan penyalur Dana CSR perusahaan-perusahaan Swasta Nasional maupun Multinasional di seluruh Wilayah Republik Indonesia untuk di salurkan dan dikembangkan supaya tepat sasaran dalam rangka pemerataan kesejahteraan dan pembangunan yang bekerjasama dengan Pemerintah, LSM (Lembaga Swadaya Masyarakat) dan pihak lainnya yang memiliki Visi Misi yang sama.

LPCI juga berfungsi sebagai lembaga yang menyiapkan segala Perencanaan, Pengembangan, Pelaksanaan Dana CSR tersebut dengan koordinasi dengan seluruh Pihak terkait baik Pemerintah maupun Non Pemerintah.

Masih menurut Teten, Mitra kerja LPCI adalah Kementrian Sosial-RI, sebagai leading sector yang menangani urusan sosial, dimana sudah ada kurang lebih 7 Regulasi Negara kita yang yang mengatur terkait CSR, hal itu dapat dilihat pada peraturan UU Perseroan Terbatas (PT) Nomor 40 Tahun 2007, Pasal 74. UU Penanaman Modal Nomor 25 Tahun 2007, Pasal 15. UU Migas Nomor 22 Tahun 2001, Pasal 13. UU Nomor 13 Tahun 2011, tentang 
penanganan Fakir Miskin. Pasal 36. PP (Peraturan Pemerintah) No 47 Tahun 2012, tentang tanggung jawab sosial dan lingkungan. KEPMEN BUMN Per-05/MBU/2007, tentang Program Kemitraan Bina Lingkungan (PKBL) dan PERMEN (Peraturan Menteri) Sosial-RI Nomor 13 Tahun 2012, tentang Forum tanggung Jawab Dunia Usaha dalam Penyelenggaraan Kesejahteraan Sosial.

\section{METODE PENELITIAN}

Penelitian ini menggunakan metode dasar kualitatif dengan pendekatan eksploratif deskriptif. Pendekatan eksploratif adalah metode penelitian yang bertujuan menghimpun informasi awal yang akan membantu menetapkan masalah. Sedangkan penelitian deskriptif mempelajari masalah-masalah masyarakat, serta tata cara yang berlaku dalam masyarakat serta situasi-situasi tertentu, termasuk tentang hubungan, kegiatan-kegiatan, sikap-sikap, pandangan-pandangan, serta proses-proses yang sedang berlangsung dan pengaruh dari suatu fenomena.

Untuk mendapatkan data objektif maka penelitian ini menggunakan data sekunder yang diperoleh dari beberapa wesite, artikel-artikel, jurnal, berita serta studi pustaka guna mempelajari landasan teori dan berbagai argumen masyarakat yang ada hubungannya dengan permasalahan yang diteliti.

\section{PEMBAHASAN}

\section{Penyaluran Dana CSR ke Industri Pariwisata Halal}

CSR (Corporate Social Responsibility) merupakan alokasi dana khusus dari perusahaan BUMN dan swasta untuk membantu kepentingan sosial masyarakat disekitar lingkungannya, seperti dalam bidang kesehatan, pendidikan, kemanusian, kelestarian lingkungan dll.

Dana yang dikeluarkan untuk CSR dapat dikatakan tidaklah sedikit, Perusahaan BUMN wajib menyerahkan 2,5\% keuntungan bersihnya untuk CSR, sedang besaran untuk perusahaan swasta bervariasi dari kisaran 1 juta rupiah hingga puluhan juta tergantung pada standing posision dan profit perusahaan (Norajila Che Man, Nor Azlina Abd Wahab, Norafifah Ab Hamid, \& Noraini Abd Muaziz, 2017). Hal ini diatur dalam Peraturan Menteri Sosial RI Nomor 13 Tahun 2012 tentang Forum tanggungjawab dunia usaha dalam penyelenggaraan Kesejahteraan Sosial.

Penyaluran dana CSR dari perusahaan secara ringkas dapat dilihat dari gambar dibawah ini: 


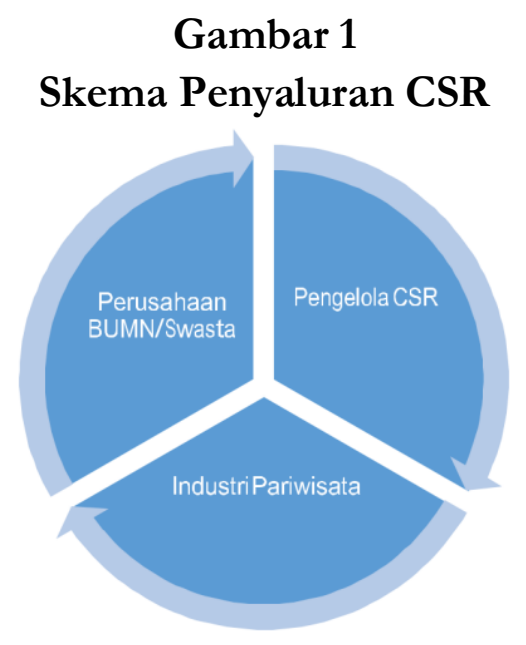

Keterangan: Perusahaan atau investor menyalurkan sebagian keuntungannya melalui Lembaga Penyaluran CSR Indonesia (LPCI). Kemudian LPCI lah yang mengelola dana tersebut kemudian disalurkan ke industri pariwisata yang membutuhkan untuk dikembangkan menjadi pariwisata halal. Setelah terwujudnya pariwisata halal dan menghasilkan omset atau keuntungan besar dari industri pariwisata maka akan dikembalikan dana yang telah diberikan LPCI tersebut dalam jangka waktu yang telah disepakati. Sebelum LPCI menyalurkan dana, industri pariwisata dalam hal ini Bledug Kuwu mengajukan proposal kerjasama mengenai pembiayaan untuk pariwisatanya kepada Lembaga Penyaluran CSR Indonesia Penyaluran dana CSR ke industri pariwisata halal mengenai wisata Bludug Kuwu yang berlokasi di kabupaten Grobogan akan difokuskan ke berbagai aspek dalam pembangunan yaitu: meperbaiki infrastruktur, membangun fasilitas yang memadai bagi wisatawan, menyediakan warung atau toko disekitar lokasi pariwisata, meningkatkan sumber daya manusia untuk pelayanan dalam mengelola lokasi pariwisata dan melakukan reboisasi.

Dalam hal memperbaiki infrastruktur ini terlebih pada pembangunan akses jalan menuju lokasi pariwisata, selain itu juga membangun tempat parkir yang luas dan terjamin keamanannya, kapasitas parkir yang tercukupi juga menjadi poin penting dalam tata ruang infrastuktur. Bagitupun juga dalam hal membangun fasilitas-fasilitas yang memadai untuk wisatawan, tempat pariwisata dibangun fasilitas-fasilitas yang ada pemisah antara wisatawan perempuan dan laki-laki untuk menunjang wisatawan yaitu berupa membangun masjid atau musholla untuk kepentingan ibadah, kamar mandi atau toilet yang tersedia dengan tempat air wudhu, tempat peristirahatan pengunjung seperti gazebo atau tempat duduk.

Untuk meningkatkan perekonomian masyarakat, dana CSR perlu juga menitikberatkan pada penyediakan warung atau toko disekitar lokasi pariwisata. Nantinya 
akan membangun beberapa toko untuk disewakan bagi masyarakat sekitar yang berfungsi menjual berbagai makanan dan minuman yang berlabel halal, sehat dan bersih (Waharini \& Purwantini, 2018).

Meningkatkan sumber daya manusia perlu juga dilakukan untuk meningkatkan pelayanan dalam mengelola lokasi pariwisata. Pendanaan ini untuk pemberdayaan masyarakat melalui sosialisasi dan pelatihan secara berkelanjutan sampai benar-benar dapat mewujudkan dan mengembangkan pariwisata halal tersebut dengan mandiri. Selanjutnya tugas terakhir adalah mMelakukan reboisasi, hal ini dilakukan karena iklim tempat pariwisata cenderung panas dan gersang, dengan demikian, reboisasi perlu dilakukan di setiap titik lokasi pariwisata dengan tujuan agar tempat pariwisata tersebut menjadi nyaman dan rasa panas terkurangi secara signifikan karena teriknya matahari pada siang hari bagi wisatawan yang berkunjung.

Pendanaan CSR pada aspek-aspek industri pariwisata yang telah ditelusuri secara detail memberikan manfaat yang dapat membantu peningkatan perekonomian masyarakat sekitar lokasi wisata dan membantu dalam peningkatan pendapatan perekonomian daerah setempat.

\section{Pengelolaan Potensi Halal Di Bledug Kuwu}

Dewan Syariah Nasional (DSN) MUI telah menerbitkan Fatwa Nomor 108/DSNMUI/X/2016 tentang pedoman penyelenggaraan pariwisata berdasarkan prinsip syariah yang menjadi landasan standar aspek-aspek wisata halal. Terlebih, aturan mengamanatkan usaha yang dijalankan dengan prinsip syariah harus memiliki landasan fatwa dari DSN MUI, termasuk perusahaan terbatas. Sekretaris Bidang Bisnis dan Wisata DSN MUI Moch. Bukhori Muslim menjelaskan, mulai 2016, mulai banyak permintaan fatwa tentang RS syariah dan wisata halal. Di Fatwa No 108/2016 tentang pedoman penyelenggaraan pariwisata berdasarkan prinsip syariah, aspek pariwisata yang ada di dalamnya adalah hotel, spa, sauna, dan massage, objek wisata, dan biro perjalanan. Semua elemen yang ada di fatwa akan ada standarnya. Fatwa No 108/2016 ini sendiri merupakan pedoman umum standar aspek pariwisata halal. Agar implentasi fatwa ini bisa lebih cepat, DSN akan bekerja sama dengan berbagai pihak untuk membuat standar.

Konteks pengertian wisata halal yang melayani kebutuhan dasar wisatawan muslim mulai dari makanan, minuman hingga pelayanan yang memiliki jaminan halal, tempat tinggal dengan fasilitas ibadah seperti adanya masjid atau musholah beserta perlengkapan sholat serta yang lainnya secara bertahap akan dilakukan di wisata Bledug Kuwu yang berlokasi di Kabupaten Grobogan. Sebagai salah satu destinasi yang ada di daerah Grobogan, menjadikan Bledug Kuwu sebagai salah satu pilihan tempat wisata yang perlu kita jadikan sebagai pariwisata halal terbaik di daerah tersebut bahkan se-Jawa Tengah bagi wisatawan, 
khususnya wisata muslim dan mampu menjadi pintu masuk untuk menarik wisatawan, baik dari wisatawan daerah sekitar maupun luar kota.

Bledug Kuwu merupakan destinasi wisata satu-satunya yang ada di Indonesia yang mengeluarkan semburan lumpur dan memiliki beberapa manfaat diantaranya: semburan air dari dalam Bledug Kuwu yang mengandung garam dapat dikelola untuk dihasilkan berupa garam dapur untuk bahan makanan, lumpur Bledug Kuwu, ternyata lumpur ini dapat dijadikan sebagai bahan kecantikan bagi kaum hawa dengan dikelola sebagai produk luluran atau kosmetik, serta Bledug Kuwu dapat mengalirkan arus listrik yang begitu besar dan bermanfaat bagi masyarakat. Maka dari itu kita perlu mengembangkan potensi yang besar itu untuk kita kelola sebagai destinasi wisata halal yang memberikan edukasi kepada masyarakat mengenai kemanfaatan Bledug Kuwu tersebut.

Faktor kunci keberhasilan dan pengembangan kawasan wisata Beledug Kuwu ini melakukan review master plan dan penyusunan perencanaan secara rinci, kemudian membangun kawasan balal tourism dari beberapa aspek, baik pembangunan, pelayanan dan yang lainnya. Beberapa dukungan pembangunan infrastruktur dilakukan yaitu, pengembangan, pengelolaan sarana air dan memperbaiki fasilitas-fasilitas yang sudah dimakan usia.

Dalam pengelolaan pariwisata halal melalui dana CSR, Bledug Kuwu dapat menerapkan 2 strategi utama dalam mengembangkan wisata, yaitu tata Ruang perencanaan yang bertujuan untuk mensejahterakan masyarakat yang berkunjung ke wisata Bledug Kuwu secara berkelanjutan. Tata kelola perencanaan ini lebih terfokus pada memperbaiki aksesibilitas untuk menuju ke Bledug Kuwu, menyediakan atau menjual makanan dan minuman yang tejamin kehalalannya, menyediakan sarana untuk ibadah para wisatawan, Merenovasi fasilitas-fasilitas yang sudah ada untuk ditingkatkan kualitas kebersahan dan pelayanannya, pengelolaan sarana dan prasarana dengan manejemen yang baik, Tersediaanya pelayanan saat bulan Ramadhan, fasilitas yang privat (tidak bercampur baur secara bebas antara wisatawan perempuan dan laki-laki), pengelolaan sarana air, karena kondisi yang gersang sehingga ketersediaan air bersih jadi kurang. Sehingga memperhambat aktivitas ibadah wisatawan, Penyediaan tempat sampah yang cukup supaya wisatawan tidak membuang sampah sembarangan, Peran penting pemerintah dalam mengatur wisata tersebut supaya menjadi wisata halal tourism yang diminati wisatawan dan pembangunan rumah produksi untuk memasarkan hasil dari Bledug Kuwu, seperti garam, lulur dan yang lainnya. Produk-produk yang dihasilkan oleh Bledug Kuwu inipun harus didisbusikan ke tempat-tempat yang layak untuk dipasarkan agar bias memberikan manfaat kepada orang lain dan juga membantu perekonomian masyarakat sekitar Bludug Kuwu.

Amenitas atau fasilitas penunjang menjadi suatu yang penting dalam pengembangan suatu wisata, seperti fasilitas kesehatan dan keselamatan dengan standar nasional diperlukan 
untuk mendukung kegiatan wisata seperti kegiatan di tepi bledug, saung, mushollah, atau yang lainnya, termasuk di dalamnya dalam hal fasilitas untuk meningkatkan kebersihan dan sanitasi. Selain itu, atraksi sebagai hal daya tarik wisatawan yaitu penerbangan lampion, penyediaan spot foto-foto, bazar produk atau makanan tradisional.

Optimisme ditunjukkan dengan keseriusan pembangunan kawasan wisata Bledug Kuwu diharapkan mampu menyumbangkan dengan maksimal untuk menarik kunjungan wisatawan sebanyak-banyaknya demi tercapainya halal tourism pada tahun 2022 dengan mengembangkan aksesibilitas, amenitas, atraksi, yang menjadi fokus dalam pembangunan pariwisata karena atraksi menjadi daya tarik tersendiri dalam melakukan wisata dengan adanya fasilitas dan infrastruktur yang baik dan tentunya membuat wisatawan menjadi lebih aman dan nyaman.

Dalam konteks pengertian wisata halal yang melayani kebutuhan dasar wisatawan muslim mulai dari makanan dan minuman yang memiliki jaminan halal, maka perlu juga sumber daya manusia untuk melayani dan mengembangkan tempat lokasi pariwisata dengan sebaik-baiknya .

\section{Meningkatkan Kualitas Sumber Daya Manusia}

Dalam Fatwa DSN Nomor 108 Tahun 2006 tentang pedoman penyelenggaraan pariwisata berdasarkan prinsip syariah terdapat ketentuan standardisasi dan Sumber Daya Manusia (SDM). Untuk meningkatkan SDM serta tercapainya di derah Grobogan terutama warga sekitar Bledug Kuwu maka Lembaga Penyaluran CSR Indonesia (LPCI) bekerja sama dengan Dinas Pariwisata daerah setempat untuk menggait karang taruna dan memberi pembekalan prihal Pariwisata Halal sehingga remaja karang taruna tersebut bisa menerapkannya di Bledug Kuwu, sebagai petugas atau sebagai pemandu wisata dengan persyaratan lolos seleksi. Sebagaimana dalam pedoman penyelenggaraan pariwisata dalam poin kesepuluh prihal ketentuan terkait pemandu wisata syariah.

Pemandu Wisata Syariah wajib memenuhi ketentuan-ketentuan berikut: Pertama, memahami dan mampu melaksanakan nilai-nilai syariah dalam menjalankan tugas, terutama yang berkaitan dengan fikih pariwisata. Kedua, berakhlak mulia, komunikatif, ramah, jujur dan bertanggungjawab. Ketiga, memiliki kornpetensi kerja sesuai standar profesi yang berlaku yang dibuktikan dengan sertifikat dan keempat berpenampilan sopan dan menarik sesuai dengan nilai dan prinsip-prinsip syariah.

Sehingga dengan pelatihan dan pendampingan dari Dinas Pariwisata setempat membuat peserta yang lolos seleksi menjadi kompeten dalam menjalankan tugasnya dengan baik dan benar sesuai dengan standarisasi sebagai pemandu pariwisata (Invesments, 2016). Dan menjadikan Bledug Kuwu tidak hanya sekedar Pariwisata Halal saja, namun juga sebagai lapangan pekerjaan bagi masyarakat. Akan nantinya pemandu wisata akan mendampingi wisatawan dalam melihat-lihat wisata Bludug Kuwu dan memberikan edukasi 
perihal sejarah hingga pemanfaatan hasil dari lumpur Bludug Kuwu tersebut, yang dikarenakan Bludug Kuwu menghasilkan beberapa manfaat seperti: pembuatan garam dapur, bahan luluran kecantikan, hingga pemanfaatan listrik dari Bledug Kuwu. Sebagai salah satu destinasi yang ada di daerah Grobogan, menjadikan Bledug Kuwu sebagai salah satu pilihan tempat wisata halal terbaik di daerah tersebut bahkan se-Jawa Tengah bagi wisatawan, khususnya wisata muslim dan mampu menjadi pintu masuk untuk menarik wisatawan, baik dari wisatawan daerah tersebut maupun luar kota.

\section{Kesimpulan}

Dari Pembahasan di atas bisa kita simpulkan bahwa Indonesia berpotensi besar akan pariwisata halalnya, karena Indonesia memiliki jumlah penduduk muslim terbesar didunia dan memiliki peluang besar dalam pelaksanaannya. Bledug Kuwu merupakan satu-satunya destinasi wisata yang menyemburkan lumpur dari dalam bumi dan memberikan kemanfaatan yang besar bagi masyaraka. Melalui dana CSR yang di kelola oleh Lembaga Penyalur CSR Indonesia dapat membantu dalam pembiayaan pariwisata halal di Indonesia dengan menyalurkan dana di berbagai aspek seperti: membangun infrastruktur, fasilitas-failitas penunjang serta mengoptimalkan sumber daya manusia yang berkerja sama dengan Dinas Pariwisata Daerah

\section{DAFTAR PUSTAKA}

Adinugraha, H. H., \& Sartika, M. (2019). Halal Lifestyle Di Indonesia. An-Nisbab: Jumal Ekonomi Syariah. https://doi.org/10.21274/an.2019.5.2.layout

Adinugraha, H. H., Sartika, M., \& Kadarningsih, A. (2018). Desa Wisata Halal : Konsep Dan Implementasinya Di Indonesia. Human Falah.

Bariyah, N. O. N. (2016). Strategi Penghimpunan Dana Sosial Ummat Pada LembagaLembaga Fillantrofi Di Indonesia (Studi Kasus Dompet Peduli Ummat Daarut Tauhid, Dompet Dhuafa Republika, BAZNAS, dan BAZIS DKI Jakarta). Li Falah : Jurnal Studi Ekonomi Dan Bisnis Islam. https://doi.org/10.31332/lifalah.v1i1.472

Crescentrating. (2017). Global Muslim Travel Index (GMTI) 2017. Crescentrating.Com. https://doi.org/10.1016/j.jweia.2015.05.010

Hakim, A. A., Ridwan, H., Hasanuddin, M., \& Al-Hakim, S. (2017). Towards Indonesia Halal Tourism. AHKAM: Jurnal Ilmu Syariah. https://doi.org/10.15408/ajis.v17i2.6243

Invesments, I. (2016). Industri Pariwisata Indonesia.

Jaelani, A. (2017). Industri wisata halal di Indonesia: Potensi dan prospek. Mpra. https://doi.org/10.13140/RG.2.2.29350.52802

Norajila Che Man, Nor Azlina Abd Wahab, Norafifah Ab Hamid, \& Noraini Abd Muaziz. (2017). Tanggungjawab Sosial Korporat (CSR): Penelitian Menurut Perspektif Al-Quran. In Filantropi Memperkasa Kewangan Islam.

Nugroho, L., Utami, W., \& Doktoralina, C. M. (2019). Ekosistem Bisnis Wisata Halal dalam 
Perspektif Maqasid Syariah (Halal Tourism Business Ecosystem in the Maqasid Syariah Perspective). Perisai: Islamic Banking and Finance Journal. https://doi.org/10.21070/perisai.v3i2.1964

Rama, A. (2014). Potensi Pasar Produk Halal Dunia. Fajar.

Retno, R. D., \& Priantinah, D. (2012). Pengaruh good corporate governance dan pengungkapan corporate social responsibility terhadap nilai perusahaan (studi empiris pada perusahaan yang terdaftar di bursa efek indonesia periode 2007-2010). Nominal, Barometer Riset Akuntansi Dan Manajemen. https://doi.org/10.21831/nominal.v1i2.1000

Sabdaningsih, A. (2018). Mitologi Dan Sains: Bledug Kuwu di Kabupaten Grobogan. Sabda: Jurnal Kajian Kebudayaan. https://doi.org/10.14710/sabda.13.1.7-17

Soebagyo, S. (2018). Strategi Pengembangan Pariwisata Di Indonesia. Liquidity. https://doi.org/10.32546/lq.v1i2.145

Tanudjaja, B. B. (2006). Perkembangan Corporate Social Responsibility Di Indonesia. Nirmana.

Waharini, F. M., \& Purwantini, A. H. (2018). Model Pengembangan Industri Halal Food di Indonesia. Muqtasid: Jurnal Ekonomi Dan Perbankan Syariah. https://doi.org/10.18326/muqtasid.v9i1.1-13

Zulaekah, S., Yuli Kusumawati, Ilmu, F., Universitas, K., \& Surakarta, M. (2005). Halal Dan Haram Makanan Dalam Islam. Subuf. 